Monográfico / Monographic

\title{
La originalidad de las civilizaciones axiales y el libre juego de la Historia
}

\author{
The originality of axial civilizations and the free play of History
}

\author{
Juan A. Roche Cárcel \\ Universidad de Alicante, España. \\ Ja.Roche@ua.es \\ Recibido / Received: 27/04/2020 \\ Aceptado / Accepted: 17/06/2020
}

\section{RESUMEN}

Este artículo intenta precisar, en primer lugar, hasta qué punto fueron originales las civilizaciones axiales producidas en torno al 500 antes de nuestra Era. Para ello, partiendo de una Sociología comprensiva weberiana y de los métodos heurístico social e histórico, se indagará en la etimología del concepto originalidad, que resulta básico en la creatividad y que remite, dialécticamente, a los términos aledaños de "origen" y "originario". El primero supone, básicamente, un retorno al pasado $y$, el segundo una proyección hacia el futuro, algo que -como se verá- efectúa la Era Axial, uno de los momentos creativos más intensos de la historia de la humanidad. En segundo lugar, se tratará aquí la estrecha vinculación existente entre el juego y la creación de las utopías axiales y, con esta finalidad, se desarrollarán dos mapas conceptuales que delimiten los aspectos caracterizadores tanto de uno como de la otra. Después, se interrelacionarán dichas características a fin de encontrar las correspondencias de significado existente entre ellas $y$, finalmente, se concluirá desvelando tres fundamentos de la Era Axial útiles para comprender algunos de los problemas contemporáneos. Se comprobará,

\section{ABSTRACT}

This article tries to specify, first of all, to what extent the axial civilizations produced around 500 before our era were original. To do this, starting from a comprehensive Weberian sociology and the social and historical heuristic methods, the etymology of the concept of originality will be investigated, which is basic in creativity and refers, dialectically, to the neighboring terms of "origin" and "original "The first is basically a return to the past and the second is a projection into the future, something that, as will be seen, is carried out by the Axial Age, one of the most intense creative moments in human history. Secondly, will be discussed here the close link between play and the creation of axial utopias and, with this purpose, will unfold two conceptual maps that delimit the characterizing aspects of both. Later, will interrelate these characteristics in order to find the correspondences of meaning between them. Thus, it will be verified that the Axial Age is, indeed, original and that it organizes a very creative temporal narrative. Finally, we will conclude by revealing three foundations of the Axial Age, useful for understanding some of the contemporary problems. 
así, que la Era Axial es, ciertamente, original y que organiza una narrativa temporal muy creativa.
Keywords: sociology of creativity; comprehensive sociology; axial civilizations; originality; game; time.

Palabras clave: sociología de la creatividad; sociología comprensiva; civilizaciones axiales; originalidad; juego; tiempo.

\section{INTRODUCCIÓN: LA BÚSQUEDA DE LA ORIGINALIDAD EN LA CREATIVIDAD, HIPÓTESIS DE PARTIDA Y OBJETIVOS}

\section{I.1 La persecución de originalidad, una de las características más importantes de la creatividad}

Es habitual hallar en la literatura sociológica que investiga el tema de la creatividad que ésta busca la novedad, la innovación y la originalidad. Por ejemplo, para E. Durkheim (1987, p. 14), toda moral tradicional ha de ser alterada para que no se atrofie y, precisamente, esta innovación va de la mano del proceso de creación. Según Hans Joas, la creatividad intenta explorar nuevos caminos alejados de la rutina, del capricho y de lo cotidiano, de modo que esta liberación posibilita la creación y la construcción de nuevas acciones (Joas, 2013, pp. 189, 254). C. Sánchez Capdequí $(2018$, p. 6), por su parte, considera que la experiencia creativa contemporánea persigue, de una manera casi obsesiva, la novedad y la originalidad, se dirige a la construcción del individuo mismo y, por eso, es entendida como ruptura, diferencia y divergencia. También para R. Collins la originalidad y la innovación son consustanciales a la creatividad, representan realidades minoritarias y, para que fructifiquen, deben producirse en condiciones muy determinadas (Rubio Arostegui, Pecourt y Rius Ulldemolins, 2016, p. 131). Desde la sociobiología, E. O. Wilson (2018, p. 11) defiende que la creatividad significa la búsqueda innata de la originalidad.

Como no es habitual que los sociólogos precisemos qué significa la palabra originalidad, en este artículo, se analiza en profundidad la sociogénesis del concepto de originalidad y su insoslayable vinculación con la creatividad. Cómo se verá, esa originalidad, en tanto que remite al origen y a lo originante, se asocia con el juego -origen de toda actividad cultural- y con las civilizaciones axiales -germen de nuestro tiempo-. Ambos términos, por tanto, ayudan a comprender la sociedad contemporánea y, concretamente, las ansias de creatividad que poseemos, la racionalidad sujeta a fines necesariamente complementada con una emocionalidad que busca ser intensa, y la conciencia de la sociedad reflexiva.

\section{I.2 Bases teóricas y metodológicas, objetivos y estructura del artículo}

Este artículo se sustenta en las siguientes bases teóricas y metodológicas. Ante todo, el análisis parte, esencialmente, de una orientación weberiana de nuestra disciplina, es decir, en la Sociología Comprensiva o Interpretativa (Weber, 2006, pp. 13, 43-44, 172; González García, 1992, p. 37; 1998, p. 208) para la que el mundo social y las relaciones que genera están llenos de significado. Así, la "comprensión" requiere una "interpretación racional" (Weber, 1971, p. 150), mientras que la "significación" constituye el dato con el que 
el sociólogo trabaja y el que le permite, a través de los conceptos de "correspondencia en el significado" o de "afinidades electivas", encontrar los nexos comunes de las distintas dimensiones cognitivas -estética, ética, económica, política, religiosa y social- que la modernidad ha fragmentado $\mathrm{y}$, de este modo, recomponer el sentido, la "cosmovisión" (Muñoz, 2001, p. 23), y, más específicamente, la vinculación existente entre el juego creativo y las sociedades axiales.

La teoría sociológica weberiana aludida se complementa con una metodología, el "método heurístico o interpretativo" procedente de la hermenéutica, que es una ciencia muy útil para la sociología comprensiva en la medida en que su problema central es la interpretación (Ricoeur, 1985, p. 39). En efecto, se fundamenta en una reflexión filosófica -de alcance sociológico, nos parece acerca de la experiencia de la comprensión y sobre el papel axial de la interpretación de lo humano en su relación con el mundo; de hecho, lo que se interpreta con la hermenéutica social son las cosas mismas, pero vistas en su contexto. De lo que se trata, más exactamente, es de encontrar las claves profundas de los textos, es decir, de desvelar su sentido interior a partir del verbo o discurso ideológico exterior (Grondin, 2014, pp. 10-11, 43-107). Por eso, su objeto no es el lenguaje, sino un texto que nunca es autónomo, pues está contextualizado (Beltrán Villalba, 2016, pp. 3-4), constituyendo precisamente esta contextualización la clave para un sociólogo. Además, junto al contexto, en el método de la hermenéutica objetiva, la base del texto es fundamental (Beltrán Villalba, 2012, p. 21); se trata, pues, de interpretar el texto en su contexto, en este caso las religiones axiales en su tiempo y en el entorno de sus civilizaciones. Finalmente, se aplicará aquí el método histórico, pero en la medida en que ayuda a lo sociólogos a explicar la situación actual (Beltrán, 1985, p. 9).

Siguiendo estas bases teóricas y metodológicas, se perseguirán los siguientes objetivos:

1) Reseñar las más destacadas aportaciones de la Sociología que destaquen la importancia de la originalidad para la creatividad.

2) Indagar en la etimología de este último concepto, con el fin de encontrar los términos básicos con los que se asocia, particularmente con el de origen y originario.

3) Establecer un mapa conceptual del juego que delimite sus características y sus conceptos básicos.

4) Desarrollar un mapa conceptual de los aspectos fundamentales que definen a las civilizaciones axiales, tal y como han sido analizadas por los científicos sociales, ejemplificándolos en las distintas religiones que las conforman.

5) Interrelacionar los caracteres del juego, de la creatividad y de las civilizaciones axiales para hallar las "correspondencias de significado" (en términos de M. Weber) existentes entre ellos.

6) Precisar hasta qué punto fueron originales las civilizaciones axiales, es decir, cómo se vinculan con el origen y lo originario.

7) Desvelar la manera en la que las civilizaciones axiales construyen una narrativa temporal

Siguiendo, pues, los objetivos propuestos, la Sociología comprensiva y el método hermenéutico social, se ha estructurado el artículo en los siguientes apartados, dedicados, respectivamente, (II) al juego como constituyente del origen de lo humano, de la creatividad, de la cultura, de la civilización y de la Historia y (III) a la vinculación del juego y de la creatividad con las civilizaciones axiales a (I). Ambos apartados se anteceden de (I) una introducción sobre la búsqueda de la originalidad en la creatividad, las hipótesis de partida 
y los objetivos y se acaban con (IV) unas conclusiones. A su vez, estas partes se subdividen en una serie de subapartados que se concentran, respectivamente, en (I) la persecución de la originalidad como una de las características más importantes de la creatividad, en los objetivos, las bases teóricas y metodológicas y en la estructura del artículo y en la etimología del concepto de originalidad, radicada en la ligazón entre el origen y lo originario u originante; (II) en el juego como actividad peculiar de los mamíferos y de los humanos, en su definición y características y en como resulta el origen de la creatividad y de todas las actividades humanas (el mito, el rito y la Historia); (III) en el análisis de la procedencia de las utopías de la Era Axial del juego, en sus agentes creativos, en su originalidad y en cómo construye una narrativa temporal.

\section{3. La etimología del concepto de originalidad: la ligazón entre el origen y lo originario u originante.}

Originalidad se define como la "cualidad de original", "la acción o actitud originales" (Moliner, 2007) y el "hecho o rasgo original" (Seco, 1999). "Originalidad" remite a "original", que es "de origen", a "la primera de varias cosas que proceden sucesivamente una de otra" (Moliner, 2007), a la "cosa primera o primitiva, anterior a toda elaboración, cambio o sustitución" (Seco, 1999). Sin embargo, originalidad también tiene otro significado que contradice el anterior, lo "que no imita a otros" (Seco, 1999), lo "distinto a lo acostumbrado o contrario a lo acostumbrado", algo "característico", "especial", "extraordinario", "extravagante", "nuevo" y lo que está asociado a términos como "descubrir", "explorar", "innovar", "inventar"...(Moliner, 2007).

Así pues, la originalidad -lo original- remite a los conceptos de "origen" y de "originario", es decir, tanto a lo primero o primitivo como a lo producido de forma novedosa. Por consiguiente, lo originario constituye el origen de algo y lo emanado de manera innovadora, y también el momento anterior a toda transformación, de modo que el origen y lo originado u originante van juntos, ya que lo primero constituye el fundamento de lo segundo. Pero la intrincada interrelación existente entre estos términos no acaba aquí, pues lo originado tiene, a su vez, que convertirse en origen de algo, en una nueva semilla que germine una nueva planta.

Esta ambivalencia conceptual de lo que significa la originalidad, y sus dos conceptos aledaños, está muy presente en el filósofo español, Eugenio Trías (2019), cuando define, en La filosofía y su sombra, al ser humano como un "sujeto constituyente y un objeto constituido"1 y como un ser originario en ambas circunstancias (pp. 172-179). Es decir, que el humano es quien "posee un conocimiento previo y originario de su propia esencia", al tiempo que "será el sujeto libre de determinaciones que desplegará una acción originaria fundadora de "objetos", por cuanto la "historia humana, (es) el continuo hacerse a sí mismo del hombre, su continua objetivación a partir de una praxis originaria, la continua reapropiación de la objetivación por parte del sujeto".

En suma, ambos conceptos se fusionan, de manera que el origen es inseparable de lo originario y esto último de lo primero, lo que explica que, en la creación literaria, artística o religiosa -añadiríamos nosotros-, la pretendida originalidad signifique realmente una vuelta a los orígenes, sin olvidar que, tras su forma más original, ésta anuncia lo que ha de venir (Steiner, 2002, pp. 94, 164). Como se verá, es lo que sucede precisamente en las religiones de las civilizaciones axiales.

\footnotetext{
1 No solo el ser humano está constituido y es constituyente, también el mundo turbulento constituye una historia, simultáneamente, estructurada y creadora (Balandier, 2014, p. 57). Igualmente son estructurantes la cultura y la sociedad (Beltrán, 2004, p. 73), que es creada y creadora (Gurvitch, como se citó en Balandier, 2014, p. 73). Como corolario, la creatividad no puede dejar de ser también algo estructurado y estructurante, instituido e instituyente, o lo que es lo mismo, "potencia instituyente y actualización instituida" (Sánchez Capdequí, 2018, p. 6).
} 


\section{EL JUEGO CONSTITUYE EL ORIGEN DE LO HUMANO, DE LA CREATIVIDAD, DE LA CULTURA, DE LA CIVILIZACIÓN Y DE LA HISTORIA}

\section{1 El juego, actividad peculiar de los mamíferos y de los humanos}

El juego constituye una actividad común a los animales y a los seres humanos, lo que no quiere decir que no haya profundas diferencias entre ellos. La mayor atención de los progenitores ha posibilitado, desde los mamíferos y particularmente en los primates y en los humanos, una intensificación de la protección de los neonatos y que estén libres de presiones selectivas directas. De manera que, cuando los animales tienen satisfechas sus necesidades básicas y no se encuentran en situación de estrés, como respuesta a esa relación relajada, el juego posee, en ellos, potencialidades de innovación y, en consecuencia, los procesos de cambio surgen, en último extremo, del cuidado, de la imaginación y del aprendizaje. En el caso de los humanos, específicamente mediante la atención materna, los niños obtienen cuidados, amor, calor y seguridad emocional, imprescindibles para la creación de cultura, historia, religión, moralidad, ciencia, arte y literatura (Maté, 2004, p. 152; Bellah, 2017, pp. 127-138). Pero si el juego es una actividad común en los animales y en los seres humanos, éstos también presentan notables diferencias. Ciertamente, para los primates jóvenes, el juego se asocia -como en los humanos- con un elemento emocional de placer (Maté, 2004, p. 152), pero en general, para el resto del mundo animal, constituye, con sus sencillas formas, un fenómeno meramente fisiológico, biológico o físico -fundamentalmente basado en el movimiento-. Se trata, concretamente, en las secuencias de juego de movimientos exagerados, pues son una colección de "actividades traslocadas, extravagantes, fragmentadas y desmañadas". Sin embargo, el juego de reglas (game) es exclusivo de los humanos (Maté, 2004, p. 152) y, para ellos y, además, deviene una función llena de sentido (Huizinga, 1987, p. 12).

En los niños, el juego todavía es, en gran parte, similar al de los animales, si bien adopta peculiares funciones, más propiamente humanas. En primer lugar, porque les substrae de su indeterminación temprana entre la subjetividad y la objetividad, lo que les otorga una perspectiva cada vez más diversificada del mundo (Winnicott, 2013, p. 42 y ss.; Joas, 2013, pp. 164-167; Bellah, 2017, p. 713). En este sentido, el pequeño que juega se encuentra en un estado de casi alejamiento, análogo a la concentración que experimentan los niños más mayores y los adultos. Así, en el momento en el que juega, se haya en un lugar que difícilmente puede dejar y que no admite intromisiones, una zona que está fuera del individuo y que no constituye una realidad psíquica interna, aunque tampoco el mundo exterior (Winnicott, 2013, pp. 91-92).

En segundo lugar, el juego cumple la función del desarrollo ético del niño, ya que con él éste aprende a adoptar el papel del otro (Mead, 1991, p. 155; Bellah, 2017, p. 713), sin olvidar que, cuando juega, está altamente concentrado y posee una energía muy intensa (Bohm y Peat, 2007, p. 61), al tiempo que se excita su cuerpo y que obtiene placer (Winnicott, 2013, pp. 91-92). Además, el arte infantil es cercano al juego, en la medida en que -como indica Freud (1908, pp. 1343-1348)- cada niño que juega lo hace como si fuera un poeta que crea un mundo propio, si bien distingue perfectamente lo que es el juego de lo que es la realidad. Pero, en todo caso, para el pequeño, el universo imaginario es tan importante y atractivo como el real (Bellah, 2017, pp. 61, 139).

Finalmente, en una comparación del juego de los primates con el de los niños se observa que éstos juegan a perseguirse y a luchar; que desarrollan una mayor variedad de ejercicios motrices y rotacionales; que investigan y manipulan objetos más frecuentemente; y que construyen juguetes, juegan a mamás, hacen juegos simbólicos y sociodramáticos y utilizan palabras que desean desechar los juegos de reglas -games- (Maté, 2014). 
En resumen, podría decirse que la diferencia del juego de los animales -y también de los primates- con el de los humanos es de grado. En este sentido, podría definirse la actividad lúdica humana como una construcción imaginaria, simbólica, sociodramática e, incluso, política, por cuanto persigue romper las reglas establecidas. Sin olvidar que es "el juego del juego", un metajuego, no en balde en él interviene y se desarrolla la conciencia (Duvignaud, 1982, pp. 72, 84, 86) -ya se verá que esto es también clave para comprender el juego de la Era Axial-. Y en esto sucede lo mismo que con las emociones comunes a animales y humanos, transformadas por el cerebro de los últimos en sentimiento, en una sensación o estado emocional que se hace consciente (Damasio, 2010; Moscone, 2012, p. 57).

\section{II.2 Definición y características del juego}

Llegados a este punto, conviene precisar a qué nos referimos con el concepto de juego y clarificar los principales caracteres que lo delimitan y, en este sentido, se establecerá, a continuación, un mapa conceptual del mismo. Para lo primero, parece pertinente la definición de R. Caillois (1986, pp. 37-41), quien considera que el juego organiza una actividad libre, separada, incierta, improductiva, reglamentada y ficticia, que puede ser de cuatro tipos, según predomine en ellos el papel de la competencia (Agon), del azar (Alea), del simulacro (Mimicry) o del vértigo (Ilinx). D. W. Winnicott (2013, pp. 10, 81), por su parte y siguiendo a H. Mead (1938, p. 192), distingue entre el juego estrictamente definido por las reglas que ordenan su curso (game) y aquel que se desarrolla libremente (play) y entre play (sustantivo, juego) y playing (verbo substantivado, el jugar).

Y, en cuanto a los aspectos principales definidores del juego, éstos serían, entre otros, los siguientes.

Implica el automovimiento característico de lo viviente. Concretamente, realiza un movimiento de vaivén que se repite continuamente, un constante ir y venir -como el juego de las olas-, un movimiento que no está vinculado a fin o meta alguna. Esto quiere decir que, a pesar de que el juego incluya en sí mismo a la razón característica de los seres humanos, la racionalidad del juego está libre de fines. En suma, el juego es una autorrepresentación del movimiento de juego (Gadamer, 1996, pp. 20, 67-68). De hecho, el juego supone una actividad creadora libre (Huizinga, 1987, pp. 19-24; Duvignaud, 1980, pp. 7-9; Winnicott, 2013, p. 99). De hecho, los pensamientos novedosos surgen como un juego de la mente, en tanto que en ella se interrelacionan estrechamente el movimiento libre de la conciencia y de la atención con el libre juego del pensamiento. Y es que la creatividad requiere de ambas formas de libertad, que, esencialmente, son sólo una (Bohm y Peat, 2007, pp. 60, 240). En relación con ello, es/crea un orden propio, con reglas autónomas, que se tensiona con la libertad, con la incertidumbre y con el azar (Huizinga, 1987, pp. 19-24). Así, si, por un lado, deben obedecerse las reglas que el juego plantea (Gadamer, 1996, p. 71), por otro, pueden y deben cambiarse libremente (Duvignaud, 1980, pp. 7-9; 1982, pp. 23, 70).

No extrañe que el juego se escape temporalmente de la vida corriente y que, por eso, posea una tendencia propia (Huizinga, 1987, pp. 19-24). No en balde, su tiempo y espacio son distintos a los de la vida cotidiana, ya que está encerrado en sí mismo y limitado (Huizinga, 1987, pp. 19-24; Gadamer, 1996, p. 67). En efecto, tiene lugar en un espacio y tiempo delimitado, puesto que los episodios de juego comienzan y finalizan; es más, ejercita una experiencia espacio-temporal continua (Winnicott, 2013, pp. 83, 96; Bellah, 2017, p. 140). En cuanto al espacio, el juego deja siempre un espacio que hay que rellenar -como en el Génesis, pues al estar las cosas sin nombrar, dispone que los humanos posean una capacidad para crear-, por lo que se encuentra en continua transición (Gadamer, 1996, pp. 20, 21, 73). Y, en relación con el tiempo, no regenera el pasado ni revoca las instituciones existentes, por cuanto que es una actividad inútil, vacía de todo contenido, que abre en la vida cotidiana un hueco 
(Duvignaud, s. f., p. 37). No extrañe que la "intencionalidad 0" (Duvignaud, 1982, pp. 25, 126) se alcance únicamente en el juego, lo que le asemeja a la fiesta que, en la medida en que, a pesar de que es "devorada" o "digerida" por las instituciones organizadas, aparece en un momento a-histórico y como una a-estructura dentro de las estructuras sociales.

Por lo demás, el juego pone un exceso (Gadamer, 1996, p. 20), intrínsecamente excitante y, paradójicamente, precario (Winnicott, 2013, p. 98). No es gratuito que genere una extrema intensidad de las sensaciones, de las emociones, de los sentimientos o de las ideas y que una potente energía mental e intelectual ${ }^{2}$ (Duvignaud, s. f., pp. 37-39). Como tampoco lo es que produzca un hacer comunicativo que no conoce la distancia entre el que juega y el que mira. Como muestra de ello, uno de los impulsos básicos del arte moderno consistió en abolir la distancia existente entre la audiencia, los consumidores o el público y la obra (Gadamer, 1996, pp. 69-70).

Finalmente, el juego construye un espacio de conflicto, pero también de convivencia, conciliación y pacto entre dos elementos diversos y plurales (Gregori, 2002, pp. 43-46). Entre estos polos, signo de dualidad, se encuentran -como se ha visto- las normas y la libertad, ésta y el azar y la incertidumbre, lo excesivo y lo precario, así como el límite teórico entre lo subjetivo y lo que se percibe de manera objetiva. Igualmente, el juego se ubica en la intersección entre el mundo exterior y el interior, en esa tierra de nadie donde se reencuentran las preocupaciones subjetivas y la vida cotidiana, la llave necesaria para vincular las representaciones a los hechos y para construir el prototipo de toda experiencia cultural significativa, comenzando por el arte y la religión (Winnicott, 2013, p. 96; Duvignaud, s. f., p. 33; Carolis, 2017, p. 109). Sin olvidar que el "impulso del juego" se desarrolla entre la sensibilidad y la razón, dos elementos constitutivos de la naturaleza humana, intentando equilibrarlos para que ninguno de ellos predomine (Schiller, 1990, pp. 363-365; Gregori, 2002, p. 44) y sin impedir que se expandan libremente (Schiller, 1985, pp. 89-90; Gregori, 2002, p. 45).

Vinculado con ello, la conciliación o el conflicto se establece entre dos tipos de juego: el impulsivo, que es originario y, otro, que es una aplicación del impulso originario. De ahí que, en el juego, se asocie el origen con el conflicto -entre la sensibilidad y la razón- y se imagina una relación entre él y la Historia, entendida ésta como temporalidad -origen- y conflicto (Gregori, 2002, p. 47).

\section{II.3 El juego, origen de la creatividad y de todas las actividades humanas (el mito, el rito, la religión y la Historia)}

Desde la perspectiva que se presenta aquí es importante subrayar que el juego es universal y común a los niños y a los adultos y, sobre todo, que representa uno de los orígenes de la humanización, de la propia actividad creadora (Winnicott, 2013, p. 100), así como de la cultura y de la civilización.

De la humanización, porque el juego -y la disposición anímica, psíquica y sociológica que genera- deviene una tarea fundamental de la vida humana; es una forma básica de vida (Winnicott, 2013, p. 96). Y hasta al punto lo es que, según, escribe F. Schiller, en Kallias. Cartas sobre la educación estética del hombre, éste "sólo juega cuando es hombre en el pleno sentido de la palabra, y sólo es enteramente hombre cuando juega". De hecho, -como subraya este mismo filósofo-, aunque los animales también juegan, el juego propiamente humano se caracteriza por desarrollarse en el espacio en el que se reúnen la razón y la

2 La creatividad también genera una intensidad emocional -o, mejor, en términos sociológicos, una "efervescencia" (Durkheim, 2017, p. 156) o una "energía emocional" (Collins, 2009, p. 141 y ss.). Lo importante de ambas efusividades, "excesos", en términos de juego (como se va a ver a continuación), y de ahí su posible aplicación a la creatividad y al propio juego, es que se producen en determinados momentos -en nuestro caso, durante el proceso creador y de juego de las civilizaciones axiales-y no de una manera constante. 
sensibilidad y, al cumplir tal función, humaniza (Schiller, 1990, pp. 241, 363-365). Relacionado con ello, conviene tener presente que el juego es una experiencia creadora que parte de la personalidad y que, simultáneamente, construye la persona (Winnicott, 2013, pp. 96$100)$, no en balde, es un nuevo tipo de capacidad que posee una gran potencialidad para desarrollar más facultades (Bellah, 2017, p. 126).

En cuanto al juego entendido como origen de la creatividad, en efecto éste constituye el prototipo de cualquier comportamiento creativo, incluso el del ser humano moderno "pecuniario" -heredero del "temperamento bárbaro"- que describe T. Veblen, en La Teoría de la clase ociosa, pues constituye un tipo ideal definido por su propensión al deporte, a los juegos de azar y a la creencia en la suerte, así como por su placer por la emulación sin objeto (Veblen, 2008, pp. 242-276).

Igualmente, no puede pensarse la cultura sin su componente lúdico (Gadamer, 1996, p. 66), como tampoco se entiende la civilización (Caillois, 1986, p. 13). Al respecto, el juego constituye la fuente originaria de todos los sistemas culturales humanos, es decir, del mito y del ritual, de la ley, de la poesía, de la sabiduría -del arte- y de la ciencia (Bellah, 2017, p. 122); se halla, pues, en el origen de la cultura (Duvignaud, 1980, p. 28; 1982, p. 40).

Así es, el lenguaje, la ciencia y la cultura en general también proceden del juego, es decir, de la enorme elaboración y potencialidad creativa que éste trae aparejado (Bellah, 2017, pp. 162-163). Especialmente esto ocurre con el arte, vinculado, en las reflexiones de I. Kant (2001, pp. 132, 258), con el juego y a éste con el trabajo -también en J. Dewey (Sabariz, 2018), en los humanos, el trabajo y el juego no son opuestos, sino interdependientes (Bellah, 2017, pp. 119, 692, 713-714)-, es decir, que el juego es una actividad autónoma -sin referentes exteriores (Gadamer, 1996, p. 20 y ss.)- y desinteresada, pero que al mismo tiempo supone cierto trabajo. También Schiller -que sigue en esto a Kant- considera que, aunque el juego humano comienza con el juego físico, puede derivar en un juego estético en el que se liberan todas las capacidades espirituales y culturales humanas (Bellah, 2017, p. 691).

Ahora bien, de entre todas estas actividades humanas, creativas, culturales, civilizadoras e históricas, destacan el mito y el rito y sus implicaciones culturales que derivan del juego, al que le deben su capacidad de anticipar el porvenir. A su vez, de estas dos últimas actividades proceden las grandes fuerzas instintivas de la vida civilizada: la ley y el orden, el comercio y el beneficio, los oficios y el arte, la poesía, la sabiduría y la ciencia (Huizinga, 1987, p. 16; Bellah, 2017, pp. 5, 163; Duvignaud, 1982, pp. 41, 72).

Del mismo modo, la religión se genera a partir del juego de los mamíferos y, más específicamente -como ya se ha anticipado anteriormente-, gracias al cuidado parental. $Y$ es que el ámbito protegido por la atención materna desliga a los niños de las presiones selectivas y, así, pueden dedicarse libremente a jugar y a crear. De ahí que el ritual se produzca en un ámbito relajado, lo que no quiere decir que no suponga un considerable esfuerzo para crear ese ámbito sosegado de juego, a diferencia del juego animal que requiere que los participantes estén nutridos y salvaguardados.

Como se va a ver en el siguiente apartado, esto es precisamente lo que ocurre con las civilizaciones axiales, en las que la estabilidad y el alimento seguro que proporcionan la agricultura, la ganadería, la artesanía y el comercio, así como la irrupción de ciudades, permite que surjan una serie de elites intelectuales y religiosas, una "clase creativa" -como diría R. Florida- (2010; Bergua Amores, Serrano Martínez, Báez Melián y Pac Salas, 2016), que se dedica, con intensidad, a crear un universo diferente al anterior. 


\section{LA VINCULACIÓN DEL JUEGO Y DE LA CREATIVIDAD CON LAS CIVILIZACIONES AXIALES}

\section{1 Las utopías de la Era Axial proceden del juego}

"Alli estaba yo -la Sabiduría- junto a Él como artífice, y constituía sus delicias cada día, jugueteando ante Él en todo tiempo" (Ortiz de Urbina, 2006, 8:30).

Como sugiere R. Bellah (2017), en La religión en la evolución humana. Del Paleolítico a la era axial (pp. 700,710), casi todas las utopías de la era axial poseen un elemento importante de juego. Al respecto, se pregunta el sociólogo si "no son acaso todas las utopías una suerte de juego fingido en el que uno puede imaginar un mundo que es en sí mismo un ámbito relajado en el que están suspendidas las tensiones habituales de la vida".

En este artículo se espera poder confirmar esta vinculación entre el juego y la civilización axial, que se toma como punto de partida, describiendo "las correspondencias de significado» existentes entre el propio juego, la creatividad y la era axial.

La comunidad arcaica juega como lo hacen los animales y los niños, es decir, dentro del marco del orden, con tensión y en movimiento, solemnidad y entusiasmo (Huizinga, 1987, p. 31). El grado de civilización se alcanza con el reemplazo paulatino de la primacía del Ilinx -vértigo-y de la Mimicry -simulacro-, característicos de la prehistoria, por la preeminencia en las relaciones sociales, en las primeras sociedades-estado que no abandonan el orden, del Agon -competencia- y de la Alea -azar- (Caillois, 1986, p. 165). En todas estas sociedades se desarticulaba temporalmente el desorden mediante el juego al someter a éste a la prueba de la burla y de la risa, es decir, al introducirlo en una ficción narrada o dramatizada que produzca ese efecto o, lo que es lo mismo, al sustituir la transgresión real por la ficticia (Balandier, 2014, p. 112). Si está en lo cierto Bellah, ahí, en ese juego fingido, es donde puede surgir la utopía.

Y ello es lo que sucede justamente en las sociedades axiales, en "el tiempo-eje", en el eje de la historia universal, como las denomina K. Jaspers. En efecto, en ellas se produce un cambio muy profundo, histórico, en el proceso espiritual acontecido entre los años 800 y 200 , concretamente, hacia el año 500 a. C. y hasta el primer siglo de la era cristiana. Y es que, en esta fase utópica y muy creativa, que se asienta en lo universal, tiene lugar el corte más profundo de la Historia en el que se origina el ser humano actual, esto es, las categorías fundamentales, con las cuales todavía pensamos y vivimos, y las religiones mundiales hoy conocidas (Jaspers, 2017, pp. 17-18; Eisenstadt, 2017, p. 75). Concretamente, las seis religiones universales -que actualmente siguen contando con numerosos fielesson las éticas religiosas confuciana, hinduista, budista, cristiana, musulmana y judía (Weber, 2017, pp. 344-345).

Pues bien, esta Era Axial puede definirse por las características que, a continuación, describo.

Su origen -al igual que el de la creatividad ${ }^{3}$ - se asienta en la crisis (Jaspers, 2017, p. 28), y en las situaciones límites a las que lleva, que es la que precipita las transformaciones. Por ejemplo, la formidable creatividad de la religión israelita constituye, en parte, una respuesta al desafío asirio, mientras que el libro indio, Manu, probablemente fue escrito

3 Sobre la vinculación entre la crisis cultural y la emergencia de la creatividad han escrito diversos autores. Por ejemplo, el científico J. Monod (2007, p. 176) defiende que la ansiedad moral constituye la fuente de toda creación. Entre los sociólogos, J. Alexander (2017, p. 318) considera que los hechos y los acontecimientos perturbadores traen aparejados nuevas oportunidades de innovación y de cambio. Según E. Durkheim (2017, p. 156), “hay períodos históricos en los que, bajo la influencia de algún descalabro colectivo, las interacciones sociales se hacen mucho más frecuentes y activas. El resultado es una efervescencia general, característica de épocas revolucionarias o creativas". De acuerdo a Z. Bauman y Bordoni $(2016$, pp. 13,18$)$, la crisis supone un período de transición que expresa algo positivo, optimista y creativo e impulsa tanto una diagnosis de la situación como un llamamiento a la acción. Finalmente, en la opinión de H. Joas (2013, p. 309), la creatividad puede representar una salida a la crisis cultural. 
en los momentos de incertidumbre y de caos que siguieron al derrocamiento de los Maurya y como un intento por conservar los privilegios de los brahmanes (Bellah, 2017, pp. 383, 461, 677). Ahora bien, la crisis que generó el período fue seguida, tras el mismo, por otras crisis, de modo que el período axial acabó -como todas las etapas históricas, a la postre- -en opinión de R. Bellah- en "fracaso", pues la Historia continuó su rumbo (Bellah, 2017, pp. $357,461)$, creando otras condiciones distintas a las del tiempo-eje que, posteriormente, impidieron u obstaculizaron la creatividad o que minimizaron su intensidad.

La Era Axial establece una etapa creativa original, por cuanto, que, simultáneamente, remite a un origen y a lo originario. Cierto, por ejemplo, los pensadores chinos intentaron retornar a lo viejo, donde hallaron posibilidades culturales profundamente novedosas y, particularmente, un nuevo vocabulario oral. Además, en el período Zhou se usó, por primera vez, lo antiguo para criticar el presente, mientras que el primitivismo taoísta terció por las épocas más sencillas del pasado, de manera que, con su evocación de la ingenua espontaneidad de la infancia -fase particularmente juguetona y creativa ${ }^{4}$-, personificó la crisis adolescente de la sociedad china de manera más próxima que cualquier otra escuela. Por otra parte, la utopía israelita se sustentó sobre la dura crítica que los profetas ejercieron frente a las condiciones en las que se hallaban los reinos de Israel y de Judea (Bellah, 2017, pp. 498, 557, 700). En todo caso, Israel y Grecia son "sociedades semillero" (Parsons, 1967, p. 507; Bellah, 2017, p. 721), que han dejado una profunda huella en las sociedades del futuro, en las actuales.

La Era Axial constituye una fase intermedia entre dos períodos de grandes Imperios y, por consiguiente, representa un intervalo de libertad (Jaspers, 2017, p. 85) y de transición socio-cultural. Al respecto, en el taoísmo todo ser humano "es rey de su país interior", pues propugna una moral que impulsa la libertad y la responsabilidad individual: "Mi destino está en mí, no en el cielo", (Schipper, 1995, pp. 507, 523, 526), mientras que la creatividad divina judía fue fundamentalmente libre, pues dio origen al mundo mediante un acto puramente volitivo (Hayoun, 1995, p. 201), sin olvidar que es siempre opcional, contingente y libre (Steiner, 2002, pp. 134-136). El gran legado de la civilización griega a Occidente es la concepción de la dignidad -Eleuthería, libertad- del ser humano como tal, de cualquier ánthropos (Festugiére, 1986).

Esta etapa posee una gran capacidad para imaginar cosas distintas a las que existen (Bellah, 2017, p. 480), especialmente utopías, incluso en la literatura taoísta de la época Han se concede un valor central a lo imaginario (Schipper, 1995, p. 514). Unido a ello, en la Era Axial se desarrolla una nueva actitud ideológica hacia el cambio, acompañada de una constante tensión entre la creación del mismo y su rechazo o intolerancia, dentro del marco simbólico institucional (Eisenstadt, 1986, p. 402). Es lo que sucede, por ejemplo, con la creatividad lumínica de la literatura védica india que muestra un carácter "ontofánico" -que manifiesta el ser- inagotable (Eliade, 2011, p. 149). A su vez, el taoísmo considera que el universo no es el resultado de un creador, sino una creación espontánea desde el caos, un devenir en perpetuo cambio "por sí mismo" que fluye en paralelo con una fuerza retrógrada, de manera que los ciclos de progreso y de regresión se equilibran. En este universo en perpetua mutación y retroceso, el ser humano ocupa un lugar insignificante (Schipper, 1995, pp. 514, 521).

La Era Axial diferencia el pasado, el presente y el futuro, creando una discontinuidad entre las principales dimensiones temporales y la subsiguiente necesidad de encontrar la manera de tender puentes entre ellas. No obstante, a pesar de que la naturaleza de este puente, ya sea cíclica, histórica o apocalíptica, es muy versátil entre las distintas civilizaciones, lo común a todas ellas es precisamente la existencia de alguna discontinuidad (Eisenstadt, 1986, pp. 388-398). Como muestra, el budismo parte del tiempo presente donde

4 Desde el psicoanálisis se insiste en vincular la creatividad con la infancia y que uno de los rasgos caracterizadores de los creadores lo constituye su infantilidad (Green, 1993, p. 209 y ss.; Gardner, 2010, p. 51 y ss.; Winnicott, 2013, pp. 42-46, 125, 163). 
se vive y da prioridad a los actos del presente (Robert, 1995, p. 445, 451), mientras que la religión judía, orientada por la Historia y el Tiempo (Eliade, 2011, pp. 44-46), constituye "la religión del tiempo", pues los judíos son los auténticos "constructores del tiempo" (Beriain, 2008, p. 43) y su Creación bíblica deviene, en sí misma, un acontecimiento histórico, el prólogo del resto de la Historia (Boorstin, 2008, pp. 24, 71).

Además, el pueblo judío crea una modalidad temporal que, claramente, distingue entre el pasado, el presente y el futuro, sin olvidar que, el mundo deja de ser eterno e inalterable, en tanto que es creado, mientras que sus órdenes actuales constituyen una construcción de la acción humana. En efecto, el mundo se transforma en un producto histórico, en un medio para la acción humana, que deja atrás el universo ocioso e inactivo del Paraíso (Cioran, 1986, p. VI). Así, deviene un producto histórico (Weber, 2017, p. 464) y, consecuentemente, queda determinado por la incertidumbre, la inseguridad y la libertad (Beriain, 2008, pp. 4446), mientras que la vida humana discurre en el tiempo lineal.

La Era Axial recoge el fruto de las primeras invenciones, pero sienta las bases de un tipo distinto de innovación cognitiva, es decir, de un nivel conceptual más abstracto (Donald, 2017, p. 70). No en balde, ya los conceptos que se introducen de inmanencia y trascendencia son categorías del pensamiento (Campbell, 2019, p. 79). Pero es que, además, en el caso de la historia del Antiguo Testamento posee un acento antinatural, en la medida en que consiste en el enfrentamiento de Yahvé con los cultos de la Naturaleza -la expulsión del paraíso (Frye, 1988, p. 93), la maldición del suelo (Cencillo, 1970, pp. 65, 123, 230), la difamación de la serpiente (Billinghurst, 2007, p. 22) y la condenación de Eva (Frye, 1996, pp. 189, 254, 256; Campbell, 2015, p. 34)-. El antimaterialismo también se evidencia en Platón, quien, en el Timeo, escribe que el mundo está formado con ideas puras y con sustancias inmateriales impuras (Boorstin, 2008, p. 52). El confucionismo define la moral como el descubrimiento del sentido del ser en lo más profundo de uno mismo (Vandermeesch, 1995, p. 570), mientras en la religión hindú existe una conciencia personal intermedia entre el flujo caótico de los datos sensoriales y las referencias abstractas de la metafísica racional (Hulin y Kapani, 1995, p. 400). Finalmente, en el budismo, su fundador expuso una "disciplina mental" que había alcanzado desarrollando sus capacidades interiores. De hecho, le interesa más entender las cosas interiores que las exteriores (Robert, 1995, pp. 440, 445).

La historia de la Era Axial está repleta de intentos de fusión, unidad e, incluso, de universalización. Por ejemplo, en el taoísmo, el individuo y el mundo constituyen una unidad (Schipper, 1995, p. 526), mientras que igualmente en la religión hindú, no se establece ninguna frontera rígida entre lo visible y lo invisible, lo animado y lo inanimado, el ser humano y el animal (o el vegetal) y entre las conciencias humanas mismas, como si un único aliento vital animara todas las cosas. Así pues, para los hindúes, las parejas de opuestos constitutivas del universo, se funden en un poder impersonal y neutro (Hulin y Kapani, 1995, pp. 338, 398).

La historia de la Era Axial también está llena de tensiones, dualizaciones y antagonismos, pues confronta constantemente el cambio y la intolerancia al mismo, o la ortodoxia, por un lado, y la escisión y la heterodoxia, por otro. Junto a ello, se contraponen también lo ancestral e inmemorial al lado de lo subversivo y de lo herético (Knöbl, 2017, p. 294; Sánchez Capdequí, 2018, p. 4). Asimismo, desarrolla una visión dualizada del mundo y fuertes tendencias antagónicas, que, desde entonces, han ocupado un rol fundamental en la historia de la humanidad (Eisenstadt, 2017, p. 79). Por ejemplo, es lo que ocurre con Grecia, con una clara conciencia de la polarización, del dualismo en el mundo y en la sociedad, lo que conduce a clasificar a todos los seres y a las cosas en una serie de oposiciones (Roche, 2017).

Pero, quizás, una de las tensiones más importantes es la que se establece, entre el orden mundano o inmanente y el trascendental (Eisenstadt, 2017, p. 75), con el que aparece, 
asimismo, la necesidad de reconstruir el orden mundano (Knöbl, 2017, p. 284). Se explica, así, que, aunque la vieja unidad del poder político y del religioso continue (Bellah, 2017, p. 340), se desarrolle una honda reordenación de las relaciones entre el orden político y el trascendental superior, puesto que el primero, que representa al orden mundano, ha sido concebido, generalmente, como inferior al trascendental y se reestructura de acuerdo con los preceptos del segundo (Eisenstadt, 1986, p. 394). Esto es lo que ocurre, justamente, en el caso de las nuevas religiones de redención axiales en las que la tensión con los órdenes políticos del mundo tuvo que agudizarse todavía más por la ética de fraternidad que propugnaban (Weber, 2017, p. 417). Así sucede, por ejemplo, para los hindúes, las parejas de opuestos constitutivas del universo, se funden en un poder impersonal y neutro. Ello porque el brahmán posee una dimensión trascendente absoluta, situada más allá del tiempo, mientras que la dimensión de inmanencia se encuentra en el seno del mundo creado. Ello explica que se establezca un corte entre el Señor supremo mismo, el creador del universo y el mantenedor de su orden inmanente, el que lo produce y reabsorbe periódicamente, y los mandalin, esto es, los "regentes cósmicos" que pertenecen, como los seres humanos, al mundo y al tiempo (Hulin y Kapani, 1995, pp. 339-340, 405).

Por otra parte, de la relación con el dios trascendente y con el mundo, entendido como una criatura corrupta y éticamente irracional, procede la pérdida de santidad de la tradición y la necesidad de trabajar permanentemente, y siempre de forma incompleta e inacabada. Esto se ejemplifica muy bien con la concepción inestable helena del mundo y del ser humano (Castoriadis, 1998, pp. 70, 115 y ss.; 2006, pp. 10, 45-358), que defiende, desde la perspectiva de C. Castoriadis, que el "ser social es caos, indeterminación y creación" (Cristiano, 2009, p. 105); con una creación -la Teogonía de Hesíodo- que conduce a una vida, eternamente renovada con la creatividad (Steiner, 2002, pp. 45, 95, 264); o con una Constitución, siempre en proceso y nunca cerrada ni inamovible (Iriarte, 2010, p. 5). También se muestra algo parecido en la religión islámica, donde se pasa "de la creación como prueba del Creador a la creación como prueba de la criatura". Y es que la creación es hecha por Dios y únicamente por él, mientras que éste elige al ser humano para ser su vicario en la tierra, por lo que éste se encuentra solo para elegir una vez tras otra (Guellouz, 1995, pp. $257,261,287)$. En la religión judía, por su parte, la creación divina, modelo de la humana, es divertida para Dios, ya que, para él, representa un gran juego con el que toma forma lo existente y con el que esto se convierte en un espectáculo. En este sentido, la creación evidencia, del lado de Dios, la risa arbitraria, mientras que, para los humanos, trasluce el ámbito de la necesidad y -como se ha visto- de la libertad, al tiempo que los riesgos producidos en el juego de la creación representan las figuras del azar (Balandier, 2014, p. 23). Por consiguiente, la peculiaridad de los seres humanos, lo que los construye como tales, es su capacidad de imitar a Dios y su manera de ejercer la potencia de la creación (Boorstin, 2008, p. 71) y ello para superar y dominar ética y racionalmente lo existente.

Se pone, así, el primer germen de lo que en la edad moderna constituirá la objetividad racional del progreso (Weber, 2017, p. 397).

\section{III.2 Los agentes creativos de la Era Axial}

Este germen de la racionalidad que instituye la Era Axial fue creado, fijado y articulado por un elemento social relativamente novedoso surgido en las estructuras burocráticas de las sociedades preagrícolas y agrícolas de la Era Axial (Donald, 2017, p. 47 y ss.). Esto es, por un nuevo tipo de élite intelectual y clerical, compuesto por los sacerdotes y los profetas judíos, los filósofos y sofistas griegos, los literati chinos, los brahmanes hindúes, los monjes Sangha budistas y los ulemas musulmanes (Eisenstadt, 1986, p. 389). 
Estos creadores del período axial tuvieron una red de continuadores -de recreadoresque expandieron las llamadas religiones universales generadas en la Era Axial. Entre éstos, destacan el burócrata ordenador del mundo, en el confucionismo; el mago ordenador del mundo, en el hinduismo; el monje mendicante que recorre el mundo, en el budismo; el guerrero conquistador del mundo, en el islamismo; el comerciante viajero, en el judaísmo; y el oficial artesano errante, en el cristianismo. Ellos son, en efecto, los mantenedores ideológicos de una ética o de una doctrina de redención que congeniaba muy bien con su posición social (Weber, 1997, p. 190). Pues bien, desde nuestra perspectiva, podrían dividirse en dos grandes grupos: los burócratas y los itinerantes o nómadas, los institucionalizadores y los transportistas o comunicadores de las ideas.

En cualquier caso, los verdaderos creadores del tiempo axial se aislaron, cuestionaron crítica y reflexivamente la realidad y observaron y concibieron una visión que iba más allá de la cotidianeidad, como hace, por ejemplo, Buda, quien critica el sistema de castas y ciertas creencias brahmánicas (Robert, 1995, p. 442). Al tiempo, en consonancia con esta cosmovisión trascendental, fueron conscientes de la necesidad de construir activamente el mundo y, por ello, promovieron los movimientos de protesta, impulsaron los conflictos e incentivaron los cambios que permitieron crear nuevos modelos, utópicos, de orden social y cultural (Eisenstadt, 1986, pp. 385-389, 400 y ss.).

En un plano mental, social y cultural, estas élites lograron pasar de un mundo mágico, fundamentalmente campesino y dominado por los hechiceros, a, otro religioso, de corte urbano con un importante rol de los sacerdotes. Y lo que es muy importante, particularmente para la historia de la civilización, consiguieron sustituir parcialmente la magia por la razón, o, mejor, sumaron a la comprensión y manipulación de este mundo y el del más allá el camino racional junto al tradicional mágico. Por ejemplo, en la antigua Grecia, donde surgen los filósofos de corte occidental, el logos es consustancial al proceso de creatividad. Este logos -como destaca Heidegger, en la Introducción a la Metafísica-, es un sustantivo que deriva del verbo légein, que significa «hablar», "referir», "seleccionar», «reunir», «ensamblar». Por tanto, todas estas acciones indican que el logos -como la creatividad- remite a una forma de pensar, de contar o computar y de relacionar (Bilbeny, 2012, p. 86). Además, «la palabra más antigua para el reino de la palabra pensado así, para decir, se llama logos... la misma palabra logos, el nombre para decir, lo es a la vez para ser, o sea, para la presencia de lo que es presente» (Heidegger, 1987, p. 213), lo que quiere decir que el lenguaje -y la creatividad- es "la casa del ser" (Trías, 1984, pp. 97-98).

Ahora bien, al lado de esta racionalidad, existen también en Grecia poderosas fuerzas irracionales de origen externo o interno -la manía, la locura, la ATE, el terror a la Míasma y a la contaminación, el Phthónos, la envidia de los dioses, la existencia continua de demonios, el miedo a la libertad del período helenístico y la diosa fortuna Tyché que, con sus vaivenes, azota a los humanos de tal modo que sus acciones -y las creativas entre ellas-, por muy racionales que sean, llevan en sí mismas algo de salvaje e inesperado, traen consecuencias imprevisibles (Dodds, 1983).

En consecuencia, según M. Weber, a partir de las civilizaciones axiales, convivirán la magia y la razón, en la medida en que, aunque la primera posee un propósito racional, éste es buscado por medios irracionales, mientras que la religión se caracteriza por objetivos progresivamente más irracionales, perseguidos por medios cada vez más racionales. En todo caso, en su forma original, la acción movida por motivos mágicos o religiosos, a partir de ahora, se orientará hacia este mundo (Weber, 2017, p. 63).

Ahora bien, el surgimiento de los sacerdotes, como un elemento social distinto a los hechiceros, distingue netamente al nuevo mundo axial del viejo. Y es que, justamente, se denominan los sacerdotes a los funcionarios de una empresa permanente y organizada de forma regular con la finalidad de influir sobre los dioses, lo que les contrasta con los 
hechiceros, que únicamente poseen recursos aislados y circunstanciales. Por su parte, el profeta proclama la verdad de la salvación en virtud de la legitimidad de su revelación personal (Weber, 2017, pp. 89, 114).

Pero la novedad también estriba en el contexto espacial en el que se produce esta transformación, por cuanto que es muy raro que el campesinado impulse la creación de una religiosidad no mágica. Al contrario, es el pequeñoburgués, en razón de su modo de vida económico, el que tiende a generar la religiosidad ético-racional, y esto no es gratuito, puesto que la vida del pequeño burgués, al menos la del artesano urbano y la del pequeño comerciante, ya no está sujeta a la naturaleza, como sí lo está la de los campesinos. Se explica, así, que, para los pequeños burgueses, la subordinación de la influencia mágica sobre los espíritus irracionales no ocupe el mismo papel que en los campesinos (Weber, 2017, pp. 142-157).

\section{3 La originalidad de la Era Axial}

Una vez descritos los aspectos fundamentales del juego, la creatividad y las civilizaciones axiales, el análisis de su interrelación ha permitido hallar las "correspondencias de significado" (en términos de M. Weber) entre ellas y comprender la Era Axial como una etapa muy original y capaz de construir una narrativa temporal, tal y como se detalla a continuación.

En efecto, la Era Axial es profundamente original -concepto éste fundamental de la creatividad-, lo que se ha constatado aquí, en tanto que retorna a un origen y construye algo originario, volcado en el porvenir. Así, al igual que sucede en la creatividad que se sustenta en la crisis y en sus situaciones límites, la crisis y las concepciones novedosas que éstas instauran también impulsan las religiones del período axial, que rompen los marcos normativos impuestos por su sociedad. Por ejemplo, la originalidad de las civilizaciones axiales se observa en el retorno hacia el origen de la civilización china, con el fin de contemplar el presente críticamente, y en el carácter originante, de "semillero", de la israelita y la griega.

Esta originalidad de la Era Axial constituye, por otra parte, un producto de su libertad creadora, lo que la asemeja al juego y a la creatividad, libres también por naturaleza, sin olvidar que, al ser el juego una actividad que está en continua transición y que se organiza en un espacio que hay que rellenar, la civilización axial representa una transición sociocultural situada entre dos imperios normativos y autoritariamente instituyentes. De ahí que, en el tiempo-eje, represente una etapa de profunda libertad, como muestra la concepción de la dignidad -Eleuthería, libertad- del ser humano, la gran aportación de la Grecia Antigua a la civilización Occidental, o el taoísmo, para el que todo ser humano "es rey de su país interior" y, por tanto, propugna una moral que impulsa la libertad. Esta libertad, por otra parte, conlleva el que los humanos devengan hacedores de una creatividad inacabada, como tiene lugar, por ejemplo, en la religión judia, establecida desde lo opcional, lo contingente, lo incierto y lo libre. O, como ocurre en la Grecia antigua, que concibe un mundo humano esencialmente inestable en el que la vida debe ser eternamente renovada mediante la creatividad y que, coherentemente, termina elaborando una constitución política incompleta, en actualización continua.

Junto a ello, al orden propio creado por el juego, le corresponde la capacidad de las civilizaciones axiales de imaginar cosas distintas, incluso en la literatura taoísta de la época Han se concede un valor central a lo imaginario. Por su parte, el antinaturalismo judío se abstrae de la naturaleza, al igual que lo hace el antimaterialismo idealista platónico, que conforma un mundo compuesto por ideas puras y por materia impura. Finalmente, las 
religiones axiales generan, con la trascendencia, un universo distinto situado más allá del cotidiano -lo mismo sucede en el juego- y de la realidad y que se observa de una manera diferente no profana, sino sagrada.

Además, la Era Axial muestra una nueva actitud ideológica hacia el cambio mismo, como sucede, por ejemplo, la creatividad lumínica de la literatura védica india que exhibe un carácter "ontofánico" -que manifiesta el ser- inagotable, o en el taoísmo, que considera que el universo no es el resultado de un creador, sino una creación espontánea desde el caos, esto es, un devenir en perpetuo cambio "por sí mismo".

Esta capacidad imaginaria se nutre -como el juego- de la ingente energía emocional, mental e intelectual y de la potente efervescencia emocional que ha desplegado la Era Axial. De ahí que el tiempo-eje pueda ser comprendido como una etapa extraordinaria de la historia de la humanidad y esto es así hasta tal punto que, de él, todavía seguimos alimentándonos hoy.

\section{4 La Era Axial organiza una narrativa temporal}

No en balde, la Era Axial construye una narrativa temporal que ha conectado el presente, con el pasado y con el futuro $y$, de este modo, ha fusionado el origen y lo originario, lo que se relaciona con su concepción del espacio y del tiempo. En efecto, la narrativa temporal de la Era Axial se produce -y en esto también existe una correspondencia de significado con el juego- en un espacio-tiempo limitado, encerrado, continuo y fuera de lo cotidiano en el que las élites intelectuales creadoras se aíslan voluntariamente de su sociedad, para, desde esa distancia, poder orientarse hacia el mundo, construirlo activamente y reforzarlo. Es lo que hace, por ejemplo, la civilización china que retorna al pasado para, desde él, criticar al presente.

Esto se une al hecho de que las religiones axiales establecen un puente histórico que constituye, en sí mismo, una narrativa temporal, aunque ésta sea de diversa naturaleza cíclica, histórica o apocalíptica. Así, la narrativa temporal de la Era Axial se evidencia con esa especie de movimiento de vaivén que, al igual que el juego, esta efectúa y que va del pasado al futuro pasando por el presente y de la crisis que la ha originado a la que la cierra. Lo primero es lo que se constata, por ejemplo, en la civilización china y que vuelve a la infancia -etapa significativamente creativa- buscando la simplicidad y huyendo de la complejidad de su etapa. Lo segundo puede llevar, tal vez, a pensar-como hace R. Bellah-, desde la perspectiva de su tiempo, que la civilización axial ha constituido un fracaso, de manera similar a cómo el juego deviene, a la postre, una actividad inútil que ni regenera el pasado ni revoca las instituciones existentes. Sin embargo, en tanto que el mito, producto del juego, consigue anticipar el porvenir, el mito de las religiones axiales han logrado también poner en práctica un sentido profético e, incluso, crear el futuro. Al respecto, conviene recordar que sus utopías, que por cierto manan del juego fingido, imaginario y creativo en el que se sustituye la transgresión de lo real por una ficticia, se ocupan -como todas- del futuro (Hudson, 1982, p. 167; Ricoeur, 1988, pp. 119-120). Y, de este modo, la realidad cotidiana sigue su curso, pero ya no desde la misma forma que antes, sino contaminada -mejor, enriquecida- por el deseo de la utopía.

A ello se le suma que la discontinuidad típica del tiempo, presente, por ejemplo, en el budismo, que parte del tiempo presente donde se vive y da prioridad a los actos del presente. También se reinventa en la religión judía, la religión judía, orientada por la Historia y el Tiempo, pues concibe el tiempo lineal, que considera al mundo como una construcción histórica y, como tal, como un medio para la acción humana y que imagina una creación del universo que se convierte en el prólogo de la Historia. 
Por consiguiente, no extrañe que esta narrativa temporal sea-como el juego- dialéctica ${ }^{5}$, pues fusiona y, simultáneamente, tensiona, confronta, dualiza y antagoniza. Lo primero, sucede, ante todo, porque la Era Axial constituye una etapa de universalización. Y es que, de manera similar a cómo el juego es universal, pues lo ponen en práctica los hombres y las mujeres y los niños y los adultos, también la era axial se asienta en la universalización. Así, la creatividad de esta etapa se ha originado en distintas partes del planeta y en diferentes civilizaciones, al igual que se produjo con el surgimiento de la agricultura.

En dos de esas civilizaciones surge un intenso pensamiento sobre la unidad, como muestran China, donde surge el taoísmo, en el que la fusión llega a su máxima intensidad, pues el individuo y el mundo constituyen una unidad, e India, donde las parejas de opuestos constitutivas del universo se funden en un poder impersonal y neutro.

Por otra parte, conviene tener presente que el juego asocia el origen y el conflicto y se desarrolla en una tierra de nadie en la que los polos enfrentados se interseccionan inseparablemente. El tiempo-eje contrasta y, al unísono, vincula el orden y la libertad, la incertidumbre y el azar, el exterior y el interior, el sujeto y el objeto, lo lúdico y el trabajo, el orden mundano y el trascendente, el espacio y el tiempo, el pasado y el presente, el presente y el porvenir, la realidad y la utopía y lo lúdico y el trabajo.

Al respecto, en esta última polarización, de la misma manera que el juego es impulsado por una racionalidad libre de fines y por la vinculación entre él y el esfuerzo, de esta racionalidad lúdica brota la racionalidad ética de las religiones axiales, que se convertirán, a su vez, en el germen de la racionalidad moderna del trabajo -Weber, dixit-.

Por otra parte, del mismo modo que el juego constituye un hacer comunicativo que elimina la distancia entre el que juega y el que observa, algo similar acontece en las religiones axiales con esos tipos sociales comunicadores y transportistas, descritos por $M$. Weber, y que son los continuadores de los prístinos creadores.

Lo segundo, la fractura o dualización del mundo se expresa en la Era Axial a través de la tensión entre trascendencia e inmanencia, lo que está presente, por ejemplo, en la religión islámica, la cual considera que la creación es hecha por Dios y únicamente por él, mientras que éste elige al ser humano para ser su vicario en la tierra, por lo que éste se encuentra solo para elegir una vez tras otra. Por su parte, en la religión islámica el brahmán posee una dimensión trascendente absoluta, situada más allá del tiempo, mientras que la dimensión de inmanencia se encuentra en el seno del mundo creado.

\section{CONCLUSIONES. TRES FUNDAMENTOS DE LA ERA AXIAL QUE AYUDAN A COMPRENDER NUESTRO TIEMPO}

Siguiendo la Sociología comprensiva de M. Weber, los métodos hermenéutico e histórico, el examen de la etimología del concepto de originalidad y los objetivos propuestos y tras interrelacionar los aspectos caracterizadores del juego, la creatividad y las civilizaciones axiales, en este artículo se han desvelado "las correspondencias de significado" existentes entre ellos. Concretamente, han quedado al descubierto tres fundamentos de la Era Axial que ayudan a comprender nuestro tiempo: es una etapa muy original y creativa, organiza una narrativa temporal, e intensifica la conciencia de lo que somos, de dónde venimos y hacia dónde queremos ir.

5 El destino humano avanza dialécticamente: dialéctica conceptual -Hegel: tesis, antítesis, síntesis, los tres estadios mediante los cuales progresa la humanidad-, de lucha de clases -Marx-, de la razón vital -Ortega y Gasset- (Ortega y Gasset, 2008, pp. 149, 173). Para Eugenio Trías, la dialéctica no estudia por separado los dos conceptos en juego (sujeto-objeto), sino la ligazón necesaria entre ambos (Trías, 2019, p. 193); en nuestro caso, sería la ligazón entre el origen y lo originario. Finalmente, interesa aquí la dialéctica por cuanto que constituye una opción metodológica que, sobre todo, persigue hallar una razón del cambio (Eco, 1972, p. 141). 
En primer lugar, la Era Axial representa un período enormemente original, y, por consiguiente, creativo, puesto que retorna al origen y construye algo originario, volcado en el porvenir. Su origen es el tiempo de crisis y de transición en el que brotan con fuerza nuevas y poderosas ideas, mientras que su carácter originario u originante nos induce a recapacitar sobre los actuales tiempos críticos, pues podrían solventarse con la creatividad -tal y como sugiere H. Joas-. Pero lo que nos enseña la Era Axial es que esto solo será posible si desplegamos dicha creatividad con libertad y teniendo en cuenta que pensar, imaginar, soñar y crear son ejercicios libres, no en balde -como defiende el taoísmo- todo ser humano, "es rey de su país interior". Además, la Era Axial -y, particularmente, el taoísmo del período Han- concedió - del mismo modo que hacen los niños- un valor central a lo imaginario y precisamente estimuló imaginar cosas distintas. Entre ellas, una nueva actitud ideológica hacia el cambio mismo, algo que en nuestras sociedades líquidas, en devenir y en flujo, constituye una de sus características más definitorias. Tampoco conviene relegar que la Era Axial supuso un intenso y efervescente despliegue emocional y de ahí que pueda ser comprendida como una etapa extraordinaria de la historia de la humanidad, hasta el punto de que todavía seguimos nutriéndonos de ella.

En todo caso, debe tenerse en cuenta que la creatividad -como ha sugerido C.Castoriadises una actividad siempre inacabada, por lo que cabe suponer que la salida a la crisis contemporánea será -como siempre lo ha sido- transitoria, que debe ponerse en juego una creatividad desbordante y que su resultado nunca puede ser ni definitivo ni completo. $Y$ en ello le ocurre a la creatividad algo similar a lo que le sucede a nuestras democracias representativas, siempre en construcción, jamás completadas totalmente -ni en la Grecia Antigua ni hoy-, constantemente en tránsito hacia su mejora y perfeccionamiento.

2

En segundo lugar, la Era Axial -como la creatividad-construye una narrativa temporal, en la medida en que retorna al origen, se distancia críticamente del presente y elabora utopías que abren sus sociedades hacia el porvenir. En efecto, en ella se han fusionado el origen y lo originario, pero esto ha ocurrido fuera de lo cotidiano, pues las élites intelectuales se han distanciado de su sociedad para poder juzgarla adecuadamente y proponer nuevas alternativas. Además, en la Era Axial, la realidad cotidiana siguió su curso, pero ya no de la misma forma que antes, sino enriquecida por el deseo de la utopía. Quizás esto nos recuerde a los contemporáneos que necesitamos como nunca utopías transformadoras de una realidad social a la que, en general, no se le ven muchas salidas.

Por otro lado, actualmente -como en la Era Axial- sigue existiendo una discontinuidad temporal que -al igual que en el budismo- da prioridad a los actos del presente, convertido hoy en un tirano (Beriain, 2008). Y seguimos orientados -como en la religión judía- por la Historia y por el Tiempo, solo que éste se ha acelerado enormemente y aquélla se ha oscurecido. Incluso, hay quien piensa que estamos en el Apocalipsis de la Historia, en su tramo final, en el fin de los tiempos, completando así el gran libro de la Historia inaugurado por el pueblo judío, que consideró que su etapa constituía el prólogo de ese gran libro. Nuestra perspectiva -como la de Negri-, pesimista de la razón y optimista de la voluntad, se resiste a pensar de esta manera y ve en la creatividad -con sus indudables limitacionesposibilidades de salida a nuestra caótica e indeterminada situación.

En este sentido, se debería tener presente que la Historia, en ocasiones, da saltos y cabriolas -como los animales cuando juegan- y que, a veces, sus movimientos son desmesurados -como los de los primates-. Pero la Historia constituye -al igual que la creatividad- una narrativa temporal que, persistentemente, mira al pasado para construir 
un presente y, desde él, el porvenir. Uno de esos saltos que efectuó la Era Axial fue hacia el territorio y el tiempo de lo trascendente y, al hacerlo, mostró una cierta distancia con respecto a este mundo, lo que ha permitido, desde entonces, contemplarlo de otra manera, más críticamente. Así, la forma de la organización social ha podido ser cuestionada y, en su lugar, se ha imaginado un universo alternativo. En este sentido, el salto del que hablamos es hacia el futuro, modelado en su origen en la Era Axial. La sociedad contemporánea, el producto originario de aquella era, es la heredera de ese salto y, por ello, tiene la responsabilidad, a su vez, de ser el origen originante del mañana.

Al respecto, caben dos reflexiones últimas. La Era Axial representa una etapa de universalización y, como tal, ha devenido un germen de los ideales cosmopolitas ilustrados y de la actual globalización. Uno de los grandes retos ante los que se enfrenta lo constituye la pandemia del COVID 19, que ha intensificado una crisis, de por sí, muy profunda y que, por consiguiente, impele a un despliegue enorme de creatividad y de energía capaz de superarla. Por otro lado, si el juego y la Era Axial constituyen un hacer comunicativo que elimina la distancia entre el que juega y el que observa, da que pensar si las actuales democracias representativas serán capaces de transformarse en parte o en el todo en democracias participativas, como reclama insistentemente una parte de la sociedad.

\section{3}

La Era Axial ha establecido que la inmanencia y la trascendencia son categorías del pensamiento, un juego mental, "el juego del juego" -como diría J. Duvignaud-, un metajuego en el que interviene y se desarrolla la conciencia. Para la religión hindú, esta conciencia se concentra más en las cosas interiores que en las exteriores y la ubica en la persona, en un espacio intermedio entre el flujo caótico de los datos sensoriales y las referencias abstractas de la metafísica racional. El confucionismo, por su parte, define la moral como el descubrimiento del sentido del ser en lo más profundo de uno mismo, al igual que el taoísmo establece que cada individuo es el auténtico rey de su país interior.

Por el contrario, la religión judía supone más una conciencia de pueblo, como ocurre en el hinduismo o en el sintoísmo, religiones de nacimiento, de parentesco (Campbell, 2019, pp. 105, 110).

Por consiguiente, la Era Axial estableció como valor fundamental de la creatividad la conciencia social o individual, esto último algo que, más adelante, Kant (2001) retomó, colocando la creatividad -y la estética que emana de ella- en la subjetividad libre (Duvignaud, 1982, p. 60 ss). Pero ambas creatividades -la social y la individual- van juntas, pues justamente la conciencia individual se establece como fundamento de la Sociedad reflexiva (Lamo de Espinosa, 1990), de la sociedad que se piensa a sí misma, que se distancia para autocriticarse y, en suma, para elaborar alternativas superadoras de sus letargos o parálisis. La sociedad reflexiva es la que juega creativamente, partiendo de su origen, de un pasado revisado, para cuestionar el presente y edificar el futuro.

Y lo hace, indudablemente, con la racionalidad, cuya raíz procede de la Era Axial. Así, esta vincula la racionalidad libre de fines desplegada en el juego, la racionalidad lúdica, con el esfuerzo y, de esta manera, brota la racionalidad ética de las religiones axiales, que se convertirán, a su vez, en la génesis de la racionalidad moderna del trabajo. Ahora bien, la Era Axial también nos ha mostrado que la racionalidad no es una fuerza suficiente en el juego creativo, que la creatividad es puesta en juego por una intensa energía emocional que se convierte en efervescente, quizás, por aquello que decía Simmel de que la vida llama a más vida. 
De este modo, puede decirse que la Historia se constituye en el día a día, en los pliegues de lo cotidiano, pero también en los profundos valles y altas montañas, en esos jalones, en esos momentos extraordinarios -como los de la Era Axial- en los que se despliega una energía emocional efervescente, "revolucionaria" -en términos de E. Durckheim-.

En este sentido, al hilo de la enseñanza de la Era Axial, cabe preguntarse si la Historia no supone, en el fondo, un salto hacia adelante, una manera de superar las crisis y una aspiración utópica de construir lo aún inexistente. Por eso, a pesar del aparente fiasco que -según R. Bellah- supone la Era Axial, con su originalidad y con su típica narrativa temporal, ha renovado la Historia, nuestra Historia, y, a través de ella, también la propia existencia de los individuos, de las sociedades, de las culturas y de las civilizaciones.

Pero, hay algo más, pues podría inferirse de todo esto que, en ocasiones, las más lúdicas, originales y creativas, se produce un extraordinario libre juego de la Historia. Y eso es lo que aconteció, justamente, en el período denominado tiempo-eje, y nada hace pensar que no pueda volver a ocurrir nuevamente.

\section{REFERENCIAS}

Alexander, J. (2017). “Trauma cultural e identidad colectiva”. En C. Sánchez Capdequí (ed.), La creatividad social: narrativas de un concepto actual. Madrid: CIS, 315-347.

Balandier, G. 2014. El desorden. La teoría del caos y las ciencias sociales. Barcelona: GEDISA.

Bauman, Z. y Bordoni, C. (2016). Estado de crisis. Barcelona: Paidós.

Bellah, R. (2017). La religión en la evolución humana. Del Paleolítico a la era axial. Madrid: CIS.

Beltrán, M. (1985). Cinco vías de acceso a la Realidad Social. Revista Española de Investigaciones Sociológicas, (29), 7-41.

Beltrán, M. (2004). La estructura social. Barcelona: Ariel.

Beltrán Villalva, M. (2012). Sobre hermenéutica: de la Filosofía a la sociología empírica. Revista Española de Sociología, (17), 9-26.

Beltrán Villalba, M. (2016). Dramaturgia y hermenéutica: para entender la realidad social. Madrid: CIS.

Bergua Amores, J. Á., Serrano Martínez, C., Báez Melián, J. M. y Pac Salas, D. (2016). La clase creativa. Una aproximación a la realidad española. Revista Internacional de Sociología, 74(2), e032. https://doi.org/10.3989/ris.2016.74.2.032

Beriain, J. (2008). Aceleración y tiranía del presente. La metamorfosis en las estructuras temporales de la modernidad. Barcelona: Anthropos.

Bilbeny, N. (2012). Ética. Barcelona: Ariel.

Billinghurst, J. (2007). Mujeres tentadoras. Barcelona: Océano.

Bohm, D. y Peat, F. D. (2007). Ciencia, orden y creatividad. Las raíces creativas de la ciencia y la vida. Barcelona: Kairós.

Boorstin, D. J. (2008). Los creadores. Barcelona: Crítica.

Caillois, R. (1986). Los juegos y los hombres. La máscara y el vértigo. México: FCE. 
Campbell, J. (2015). Las Máscaras de Dios: Mitología Occidental. Madrid: Alianza.

Campbell, J. (2019). Tú eres eso. Las metáforas religiosas y su interpretación. Girona: Atalanta.

Carolis, M. de (2017). La paradoja antropológica. Nichos, micromundos, disociación psíquica. Buenos Aires: Quadrata/Iluminuras.

Castoriadis, C. (1998). Los dominios del hombre. Las encrucijadas del laberinto. Barcelona: GEDISA.

Castioriadis, C. (2006). Lo que hace a Grecia. 1. De Homero a Heráclito. Seminarios 1982-1983. La creación humana II. Buenos Aires: FCE.

Cencillo, L. (1970). Mito. Semántica y realidad. Madrid: Biblioteca de Autores Cristianos.

Cioran, E. M. (1986). La caída en el tiempo. Barcelona: Planeta Agostini.

Collins, R. (2009). Cadenas de rituales de interacción. Barcelona: Anthropos.

Cristiano, J. L. (2009). Imaginario instituyente y teoría de la sociedad. Revista Española de Sociología, (11), 101-120.

Damasio, A. (2010). Y el cerebro creó al hombre: ¿cómo pudo el cerebro generar emociones, sentimientos, ideas y el yo? Barcelona: Destino.

Dodds, E. R. (1983). Los griegos y lo irracional. Madrid: Alianza.

Donald, M. (2017). Una aproximación evolutiva a la cultura. Consecuencias del estudio de la época axial. En C. Sánchez Capdequí (ed.), La creatividad social: narrativas de un concepto actual (pp. 47-73). Madrid: CIS.

Durkheim, É. (1987). Historia de la educación y de las doctrinas pedagógicas. Madrid: La Piqueta.

Durkheim, É. (2017). La efervescencia religiosa. En C. Sánchez Capdequí (ed.), La creatividad social: narrativas de un concepto actual (pp. 151-169). Madrid: CIS.

Duvignaud, J. (1980). Le jeu du jeu. Bolland, Paris. Mesa redonda. Nuevos horizontes. El juego. www.libertario.arte.bo/biblioteca/Mesa\%20redonda\%20Nuevos\%20Horizontes\%20 -\%20Jean\%20Duvignaud\%2C\%20el\%20juego\%20del\%20juego.html. Pp. 118. (consultado el 13 de marzo del 2020).

Duvignaud, J. (1982). El juego del juego. México: FCE.

Eco, U. (1972). La definición del arte. Barcelona: Martínez Roca.

Eisenstadt, S. N. (1986). The Origins and Diversity of Axial Age Civilizations. New York: State University.

Eisenstadt, S. N. (2017). La dimensión civilizacional en el análisis sociológico. En C. Sánchez Capdequí (ed.), La creatividad social: narrativas de un concepto actual (pp. 73-95). Madrid: CIS.

Eliade, M. (2011). Ocultismo, brujería y modas culturales. Barcelona: Paidós.

Festugiére, A. (1986). La esencia de la tragedia griega. Barcelona: Ariel.

Florida, R. (2010). La clase creativa: la transformación de la cultura del trabajo y el ocio en el siglo XXI (Vol. 117). Barcelona: Grupo Planeta (GBS).

Freud, S. (1908). El poeta y los sueños diurnos. En Obras completas (Vol. 4), (pp. 1343-1348). Biblioteca Universal Virtual. En https://biblioteca.org.ar/libros/211753.pdf 
Frye, N. (1988). El Gran Código. Barcelona: Gedisa.

Frye, N. (1996). Poderosas palabras. La Biblia y nuestras metáforas. Barcelona: Muchnik.

Gadamer, H.-G. (1996). La actualidad de lo bello. Barcelona: Paidós.

Gardner, H. (2010). Mentes creativas: una anatomía de la creatividad. Barcelona: Paidós.

González García, J. M. (1992). Las huellas de Fausto. La herencia de Goethe en la sociología de Max Weber. Madrid: Tecnos.

González Garcia, J. M. (1998). "Sociología e iconología". REIS, Revista Española de Investigaciones Sociológicas, 84: 23-43.

Green, A. (1993). Narcisismo de Vida, narcisismo de Muerte. Buenos Aires: Amorrortu.

Gregori, E. (2002). Individuo y naturaleza en Schiller. La noción de juego. Materia, (2), 35-55.

Grondin, J. (2014). A la escucha del sentido: conversaciones con Marc-Antoine Vallée. Barcelona: Herder.

Guellouz, A. (1995). El islam. En J. Delumeau (ed.), El hecho religioso. Enciclopedia de las grandes religiones (pp. 253-331). Madrid: Alianza.

Hayoun, M. R. (1995). El judaísmo. En J. Delumeau (ed.), El hecho religioso. Enciclopedia de las grandes religiones (pp. 201-252). Madrid: Alianza.

Heidegger, M. (1987). De camino al habla. Barcelona: Delós.

Hudson, W. (1982). The marxist philosophy of Ernst Bloch. New York: Springer.

Huizinga, J. (1987). Homo Ludens. Madrid: Alianza.

Hulin, M.y Kapani, L. (1995). El hinduísmo. En J. Delumeau (ed.), El hecho religioso. Enciclopedia de las grandes religiones (pp. 333-402). Madrid: Alianza.

Iriarte, A. (2010). Atenas o el arte de lo político. Revista Bitarte, 50, 29-42.

Jaspers, K. (2017). Origen y meta de la historia. Barcelona: Acantilado.

Joas, H. (2013). La creatividad de la acción. Madrid: CIS.

Kant, I. (2001). Crítica del juicio. Madrid: Austral.

Knöbl, W. (2017). El debate de "las modernidades múltiples", su fundamento sociológicoreligioso y sus escollos. En C. Sánchez Capdequí (ed.), La creatividad social: narrativas de un concepto actual (pp. 263-315). Madrid: CIS.

Lamo de Espinosa, E. (1990). La sociedad reflexiva. Madrid: Siglo XXI.

Maté, C. (2004). El juego en los antropoides y los niños. Estudios de Psicología, 25(2), 149-167. https://doi.org/10.1174/021093904323142115

Mead, G. H. (1938). The Philosophy of the Act. Chicago: The University of Chicago Press.

Mead, G. H. (1991). Espíritu, Persona y Sociedad. Persona y Sociedad desde el punto de vista del conductismo social. Barcelona: Paidós.

Moliner, M. (2007). Diccionario de uso del español Maria Moliner. Madrid: Gredos.

Monod, J. (2007). El azar y la necesidad. Barcelona: Tusquets.

Moscone, R. O. (2012). El miedo y sus metamorfosis. Psicoanálisis, 24(1), 53-78. 
Muñoz, B. (2001). Reflexiones sobre la sociología de la cultura y de la música en la obra de Max Weber: un análisis crítico. Sociedad y Utopía, 18, 23-37.

Ortega y Gasset, J. (2008). En torno a Galileo. Madrid: Revista de Occidente-Alianza.

Ortiz de Urbina, J. C. (2006). Libro de los Proverbios del Antiguo Testamento. Madrid: Akal.

Parsons, T. (1967). Sociological Theory and Modern Society. New York: The Free Press.

Ricoeur, P. (1985). La imaginación en el discurso y en la acción. De la hermenéutica del texto a la hermenéutica de la acción. Buenos Aires: Prometeo.

Ricoeur, P. (1988). Time and Narrative (Vol. III, trads. K. Blarney y D. Pellauer). London: Chicago University Press.

Robert, J.-N. (1995). El budismo. En J. Delumeau (ed.), El hecho religioso. Enciclopedia de las grandes religiones (pp. 427-474). Madrid: Alianza.

Roche, J. A. (2017). Entre el monte de Apolo y la vid de Dioniso. Naturaleza, Dioses y Sociedad en la arquitectura teatral de la Grecia Antigua. Barcelona: Anthropos.

Rubio Arostegui, J. A., Pecourt, J. y Rius Ulldemolins, J. (2016). Usos y abusos de la creatividad. Sociología de los procesos creativos, transiciones a lo digital y políticas creativas. Debats, 130(2), 125-145.

Sabariz, C. R. (2018). Una salida al dualismo: Juego y trabajo en John Dewey. Éndoxa, (41), 135156. https://doi.org/10.5944/endoxa.41.2018.16736

Sánchez Capdequí, C. (2018). Las sociologías post 68 y la creatividad social. Arbor, 194 (787), 1-11. https://doi.org/10.3989/arbor.2018.787n1008

Schiller, F. (1985). Sobre poesía ingenua y poesía sentimental y una polémica Kant, Schiller, Goethe, Hegel. Barcelona: Icaria.

Schiller, F. (1990). Kallias. Cartas sobre la educación estética del hombre. Barcelona: Anthropos.

Schipper, K. (1995). El taoísmo. En J. Delumeau (ed.), El hecho religioso. Enciclopedia de las grandes religiones (pp. 509-548). Madrid: Alianza.

Seco, M. (1999). Diccionario del español actual. Madrid: Aguilar.

Steiner, G. (2002). Gramáticas de la creación. Madrid: Siruela.

Trías, E. (1984). Drama e identidad. Barcelona: Ariel.

Trías, E. (2019). La filosofía y su sombra. Barcelona: Galaxia Gutenberg.

Vandermeersch, L. (1995). El confucionismo. En J. Delumeau (ed.), El hecho religioso. Enciclopedia de las grandes religiones (pp. 333-402). Madrid: Alianza.

Veblen, T. (2008). Teoría de la clase ociosa. Madrid: Alianza.

Weber, M. (1971). Sobre la teoría de las ciencias sociales. Barcelona: Península.

Weber, M. (1997). Sociología de la religión. Bogotá: Fondo de Cultura Económica.

Weber, M. (2006). Conceptos sociológicos fundamentales. Madrid: Alianza.

Weber, M. (2017). Sociología de la religión. Madrid: AKAL.

Wilson, E. O. (2018). Los orígenes de la creatividad humana. Barcelona: Crítica.

Winnicott, D. W. (2013). Realidad y juego. Barcelona: GEDISA. 


\section{NOTA BIOGRÁFICA}

Juan A. Roche Cárcel es Doctor en Sociología, Profesor Titular de Sociología de la Cultura y de las Artes en la Universidad de Alicante (España). ExVicepresidente de la AESCA (Asociación Española de Sociología de la Cultura y de las Artes) y ha sido hasta el año 2005 Art Network Board (Coordinador del grupo de investigación de las Artes) en la ESA (Asociación Europea de Cultura). Actualmente, es Presidente del Comité de Sociología de las Emociones de la FES (Federación Española de Sociología) 